\title{
Effect of Service Quality Dimensions on Customer Satisfaction: A Comparative Analysis of Pakistan Telecom Sector
}

\author{
Muhammad Arslan Maria Iftikhar Rashid Zaman \\ Bahria University Islamabad, Pakistan, PO box 44000, E-8, Islamabad, Pakistan \\ Email: Mariaiftikharbah@gmail.com
}

\begin{abstract}
The purpose of this study is to establish the relationship between service quality and customer satisfaction. Two main dimensions of service quality were taken i.e. reliability and empathy. This is a quantitative analysis and the data was collected in the form of communication-based questionnaires. The sample size was 400 respondents and four main telecom service providers were considered for the study. The results were calculated by analytical software SPSS-20. It was concluded that service reliability and service empathy both have an effect on customer satisfaction. It was also determined that some factors were more satisfactory than the others. The findings of study reveal that percentages of customer satisfaction change with the service quality dimensions of reliability and empathy. Overall, it can be established that there is a significant relationship between customer satisfaction and service quality dimensions of empathy and reliability.
\end{abstract}

Keywords: Service Quality, Empathy, Reliability, Customer satisfaction.

\section{Introduction}

The purpose of this study is to establish a relationship between service quality dimensions and customer satisfaction for telecom sector of Pakistan. Two of the service quality dimensions based on SERVQUAL model are taken as independent variables while customer satisfaction is the dependent variable for this research. Telecom sector of Pakistan has been taken as a unit of analysis and four major telecom service providers are taken for comparative study.

The telecom sector of Pakistan has flourished rapidly within past few years and has made big contribution to Pakistan's economy. In 2007, telecom industry grew by approximately $80 \%$ whereas average growth after 2007 has observed to be more than 100 percent. About 98 million people are found to be mobile customers in Pakistan as of 2010. Telecom industry has been the source for generating about 327.8 billion rupees in the economy and is currently one of the most greatly taxed sectors of the country. People now are relying on cell phones more than anything else. The telecom service providers are continuously coming up with different call, messaging, internet and other packages to generate better revenues for their respective companies. However, more revenues can be generated only when the demands of target market are met. Customer satisfaction is the key to success for any company dealing with products and services.

Service quality is said to be one of the major contributors of customer satisfaction and therefore it is given importance in service sector. A lot of research has been taking place for the past two decades which has thrown light on the link between customer satisfaction and service quality. Various theories and frameworks have been presented but the work by Zeithaml, Parasuraman and Berry (1988) is of prime importance. They introduced SERVQUAL model for analyzing and improving the quality for service organizations. SERVQUAL model has been used a lot in the service sector especially in the restaurants (Parasuraman, et al., 1988). Empirical work on service quality and customer satisfaction has been done by various researchers including Spreng and Mackoy (1996), Jones and Suh (2000), Coyles and Gokey (2002) and Choi et al., 2004. A lot of literature can be found on these variables from countries like USA, UK, Canada or China; however there is a dearth of literature on service quality and service satisfaction in Pakistan. A limited work has been done to establish the link between these two variables. Therefore, the aim of this study is to cover the gap by presenting empirical evidence for the telecom sector of Pakistan.

This is a quantitative research based on positivist philosophy and a deductive research approached is followed. Primary data is collected via questionnaires distributed among the mobile service customers. As this is a comparative analysis of four telecom companies, the sample size is kept large. The questionnaire is adapted from study of Zeithaml et al. (1996) and Stevens (1995) and reveals the service quality dimensions of empathy and reliability and customer satisfaction. The next section of the paper gives a comprehensive review of literature about the (Jones \& Su (Taylor \& Baker,, 1994)h,, 2000) (Coyles \& Gokey,, 2002) theories and models already established by previous researchers. The third section gives the theoretical framework representing the variables and proposed link between them. Also the research methodology would be incorporates in it. The fourth section gives analysis of data, results and interpretation finally followed by last section of the paper which will present limitations and implications for future research. 


\section{Literature Review}

A number of studies have been conducted to explore the link between service quality and customer satisfaction. A recent Nigerian study by Ojo (2010) says that in order to maintain high levels of customer satisfaction, it is mandatory for the organization to update its services according to the expectations of customers. Not only the goal should be meeting the demands, but competitive advantage comes with exceeding the demands of the customer (Ojo, 2010). This derives customer satisfaction for long-term customer retention. Also it has been found that the costs to attract new customers and retain the existing ones, there should be an appropriate method to register the feedback of the customers so that the suggestions can be implemented upon. In literature, there were found support for influence of parental attitude on behavior and purchase intention of children (Arslan, Umair, \& Zaman, 2014). As customer focused strategy is now considered a means of attaining competitive edge (Taylor and Baker, 1994), the measurement of quality is particularly essential to devise and implement a customer oriented service (MacStravic, 1977). However, if a service constantly fails to satisfy the customer, its existence is severely threatened. This is because customer who experiences a bad service will most probably relate this experience to others (Griffin, 1995). An average Asian company has a chance of losing about $20 \%$ of its customers every year (Ojo, 2010). Also cost of acquiring new customers is far more than retaining the already existing customers (Gitomer, 1998).

\subsection{Customer Satisfaction}

Customer satisfaction is key to any organization's success means that this success is directly associated with the demands of the customer. Tremendous methods have been applied to enhance the customer experiences and most of the monitoring and controlling activities have a link with marketing measures. Satisfaction can be termed as a short lived emotional condition that occurs from an intrapersonal assessment of the customer's perception with any service incident (Oliver, 1981, Brady and Robertson, 2001; Lovelock (2001). Furthermore, the customer satisfaction can be rationalized as the person's emotion of contentment or disappointment as a result of comparison of his expectation to the experience. Service satisfaction further has two general conceptualizations 1) transaction specific satisfaction and 2) cumulative satisfaction (Jones and Suh, 2000; Yi and Lia, 2004).

Transaction-specific satisfaction can be referred to the customer's assessment of the service encounter he has and the resultant reaction because of this encounter (Boshoff and Gray, 2004). Whereas cumulative satisfaction according to Cook (2008) can be defined as customer's assessment of the overall service experience to the date. Researchers also argued the positive impact of relative advantage, compatibility, obserbility and triablity on the customer's purchase intention while the complexity has the negative relation to the purchase intention (Zaman \& Arslan, 2014).

Customer satisfaction is an intensively researched area which has been subject to discussions for more than 2 decades. Currently, this phenomenon has shifted from transactional marketing to relationship marketing (Martin, Adrian and David, 2002) which means that all marketing measures are now aiming towards creating, developing and adhering to successful relational exchanges with the customers (Yi and La, 2004). According to Thomas and Getty, 1994), quality is also based on intrinsic expectation standard of an individual and as it is a self-motivated construct; more and more customer perceptions bring modifications in it.

\subsubsection{Service Quality}

Service quality does cannot have one specific definition as this phenomenon is with respect to whether expectations of the customers are fulfilled or not (Zeithaml, Berry and Parasuraman, 1993). There are however, clear conceptualizations given by various researchers about the quality of service (Holbrook, 1994). For instance in operational management, quality is been explained in terms of reliability and fitness whereas service quality is measured in terms of product attributes in terms of economics. When talking about service quality, whole service experience is taken into account which generates service satisfaction or dissatisfaction (Parasuraman et al., 1985).

Zeithaml, Parasuaman and Berry (1988) defined service quality as a level and extent of difference between the perceptions that customer has and his expectations. In order words, it is about conforming to the expectations of customers (Mevvis and Janiszewski, 2002). By measuring the quality of service, a company is able to analyze its position among the competitors to maintain strategic edge. Assessing the service quality means knowing the strengths and weaknesses of service which will help to devise new techniques to eliminate those weaknesses. The quality of service can (Dabholkar, 1995) (Soderlund \& Ohman,, 2003)be maintained by following the total quality management techniques but most effective way is to take frequent customer feedback and make necessary adjustments in the service to avoid discomfort (Lovelock, Patterson and Walker, 2001).

A detailed research on the service quality was conducted by Parasuraman, Zeithaml and Berry (1988) who distributed formal surveys among the customers related to different focus groups. They came up with the model of SERVQUAL used for measuring five dimensions of service quality namely reliability, assurance, tangibility, responsiveness, and empathy. These researchers afterwards examined the service quality through a 22 items scale made to measure customer perception based on five dimensions used for assessing the service 
quality. SERVQUAL is said to be an appropriate measure to gear up a company for quality improvement by specifying the areas which need attention (Berry et al., 1994). These areas most likely would categorize under one or more of the five service quality dimensions and hence are measurable through the SERVQUAL scale.

\subsection{SERVQUAL Instrument}

The objective measure of service quality is difficult to be exactly suitable for all services because each service is a set of distinctive characteristics. But SERVQUAL so far has been able to meet the requirements if various industries and countries and has been used for a variety of services (Cronin \& Taylor, 1994; Babakus \& Boller, 1992; Brown \& Swartz, 1989). A few researchers are against the use of SERVQUAL because of its use of gap score, perception measuring, negative words used, positive and negative worded questions, generalizability of service quality dimensions and restricting the service quality to a baseline standard good for all (Lai et al., 2007). Once more critique on SERVQUAL is that some of the minute cultural issues which are not transparent or easily understandable do effect the customer expectation about the service quality (Kettinger et al., 1994; Mattila, 1999). In order to improve the reliability aspect of this scale, various studies have used adjusted this measure in such a way that expectations and perceptions are combined and have produced good results with the help of this. Andaleeb \& Basu (1994) and Dabholkar et al., (2000) have used this method of adjusting the SERQUAL.

In case of telecommunication industry, the use of SERVQUAL has been found very reliable in various cultures and business environments (Chen and Aritejo, 2008; Sureschander et al., 2003; Ojo, 2010; Ayapong, 2011). However, the scale has to be modified for the according to the requirements of the business environment. For example, in a study by Ward and Mullee (1997), they added some more quality dimension into the SERVQUAL scale and argued that based on a customer's viewpoint it is inappropriate not to consider network quality among other quality dimensions. Service quality needs to be adjusted according to the mobile network client's perspective so that it can be properly measured. A variety of studies have been conducted in which the quality dimensions have incorporated those aspects which suit the requirements of that country or industry's customers. Some of these would be discussed in the next paragraph.

The quality of mobile services on the global level is measured by GSM, Global System for Mobile Communication which has presented a number of indicators for the mobile phone service quality. According to Sutherland (2007) these indicators are 1) access to network, 2) service ease of access, 3) service reliability and 4) service retainability. Service quality dimensions for telecommunication industry are different than that of restaurant or other services. For example, a Canadian research in 2007 conducted on a sample of 6000 mobile service users showed that important aspects of service quality includes the quality of call, billing, prices and bundled packages (Customer Satisfaction, 2007). A study conducted in 2007 by Organization of Economic Cooperation and Development (OECD) elicited that the unavailability of correct information about quality and lack of clear knowledge about the international roaming charges affected the customer's behavior adversely. This research highlighted that 'price' and 'quality' are two leading factors which are responsible for switching over to new services. Furthermore, it was determined that key factors which played a role in customers' dissatisfaction were lack of proper information sharing, inappropriate pricing, unsolicited calls and not exceeding the customer's requirements which means no value addition (DSTI, 2007).

Another study was undertaken by Finland in 2006 and other Scandinavian countries. It was found out that the imperative drivers of customer's observation of quality integrated image of the service and its personnel and the value-added services. Also pricing was considered to be one of the most important quality aspects (EPSI, 2006). According to Ozher and Aydin (2005), the service quality features that were responsible for customer satisfaction included fulfilling customers' pre-purchase expectations, empathy which means responsiveness to customer's complaints, value-added services, effective promotional techniques as well as complaint management.

Through a Greek study by Sigala (2006), it was found that pleasant interaction between customers and staff, company's reputation, personalization and customization played a significant role in setting dimensions of service quality in telecom sector. Consumer surveys conducted by McKinsey Quarterly (2004), Cap Gemini (2005) and Consumer Reports (2005) established that quality of network based on data and voice services greatly affect the consumer contentment and loyalty with respect to the service users. Sube (2012) through a research in Bangladesh instigated that service quality in the company if more than adequate implies those customers who are exceedingly satisfied and subscribers that are loyal and contented with the services are ready to recommend others. Also indulging in new techniques to increase satisfaction and develop strong reputation entails studying of the correlation among all the variables of service quality which would assist mobile service providers to uncover the appropriate measures which must be implemented to attain fidelity of customers (Sube, 2012). This will ultimately lead to increased market share.

Based on the studies conducted by previous researchers, it has been deduced that network quality, pricing and employee-customer interaction are three dominating factors which contribute to the service quality in the telecommunication industry. However there is a very limited amount of work done on service quality in telecommunication in Pakistan's context. Therefore, the purpose this paper is to have a detailed analysis of 
service quality factors in telecom sector. Four major providers 1) Mobilink 2) Telenor 3) Zong and 4) Ufone would be selected for comparative study. The next section incorporate the theoretical framework and methodology for the study.

\section{Theoretical Framework}

In this section, theoretical framework, hypothesis and methodology for the current research is presented. After the thorough review and analysis of literature, two major variables of service quality are taken 1) Reliability and 2) Empathy. The theoretical framework is adapted by a study conducted by Zeithaml, Parasuraman and Berry (1993). The reason of chosing these two service quality variables is that both reliability and empathy are the most important factors for the telecommunication service. The unit of analysis is the telecom industry from which 4 main mobile phone service providers would be tested (Ufone, Zong, Mobilink and Telenor).

The theoretical framework given in figure 1 represents the dependent and independent variables adapted from a study of Parasuraman, Zeithaml and Berry (1993) and Stevens et al (1995).

Customer satisfaction

Reliability

Empathy

Customer satisfaction has been taken as dependent variable whereas reliability and empathy are taken as independent variables which are responsible for enhancing customer satisfaction.

Fig 1: Theoretical Framework for the Effect of Service Quality Dimensions on Customer Satisfaction: A Comparative Analysis of Pakistan Telecom Industry

\begin{tabular}{|c|} 
Independent Variable \\
\hline $\begin{array}{c}\text { Service Quality } \\
\text { (Reliability, Empathy) }\end{array}$ \\
\hline
\end{tabular}

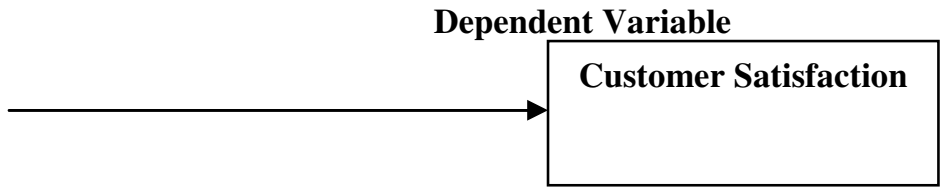

Source: Adapted from Ziethaml, Berry and Parasuranam (1993) and Hennig-Thurau and Klee (1998).

\section{Hypothesis Formulation}

After a detailed literature review, it has been found that reliability and empathy play a major role in customer satisfaction

\section{Reliability}

Reliability is the most important aspect of the service quality. According to Singh (2012), reliability refers to three important factors 1) accessibility 2) continuity and 3) performance. Accessibility is the most important aspect which means that the service is available whenever it is required and desired. In the case of telecom services, it is that the service must be provided whenever the customer wants to use it. Calling facility, signals and accessibility to all the options including the accessibility of service personnel is essential to fulfill the reliability factor of the service. The second important thing is continuity which means that the service continues to be available and up to the required standard. Maintenance of standard is imperative for adhering to the continuity factor. If the service is not continuously reliable, there is a chance that customer will not trust its reliability and will switch to the other service providers (Zeithaml, 2009). The third factor refers to performance. It includes high quality service delivery and exceeding the customers' satisfaction thus gaining their loyalty for longer time. Another factor which contributes strongly to liability in case of telecom service is the network connection. Strong network connection and its availability at all times is significant to maintain the high reputation of service (Sutherland, 2007; Sube, 2012).

Empathy

Empathy refers to the attitude of the employees towards the customer. For a service like telecom, the employees need to maintain good relationship with the customers because much interaction is involved between the two. The employees need to welcome the customer whenever they call for any query or complaint. The pleasant behavior of the employees enhances the customer experience and helps in acquiring good will for the company (Vertugo, 2009). Also timely complaint management and informing the customers about new packages or service comes under this category. Empathy brings extra value to the customers and they feel more sense of ownership for the service.

Both of these dimensions contribute towards the customer satisfaction and competitive advantage for the company. Following are the hypotheses which are derived from the dependent and independent variables.

$H_{1}$ : There is a significant relationship between reliability dimension of service quality and customer satisfaction in telecom sector of Pakistan.

$\mathrm{H}_{2}$ : There is a significant relationship between empathy dimension of service quality and customer satisfaction in telecom sector of Pakistan. 


\section{Methodology}

The study is conducted by taking Pakistan as the unit of analysis and four network service providers are taken for comparative analysis 1) Mobilink 2) Telenor 3) Zong 4) Ufone. This is a quantitative study followed with a positivist philosophy and deductive research approach. Time dimension is cross-sectional. The primary data is conducted by distributing the communication based questionnaires amongst a sample of 440 mobile services users from Pakistan out of 401 were filled. A sample of 100 individuals has been assigned for each of the telecom company. The questionnaire used is adapted from a study of Zeithaml, Parasuraman and Berry (1993) and Hennig-Thurau and Klee (1998). The data was collected in the duration of 4 weeks from the telecom service users in university, workplace and acquaintances. For the data analysis, multivariate analysis software SPSS 20 was considered for analysis of multiple response questionnaires.

The table 1 shows the reliability analysis for the questionnaire. The Cronbach alpha for each of the questionnaire items have been already determined with a few adjustments according to country's telecom services. Cronbach alpha is considered to measure the reliability of the questionnaire instruments (Cronbach, 1951). If the value for Cronbach Alpha is greater than 0.7 then the instrument is credible for the analysis. As in this study, the Cronbach alpha for each factor is above 0.6; hence it is used for further study. Each of the questionnaire items are given in the Appendix.

\section{Table 1: Reliability Analysis}

\begin{tabular}{|c|c|}
\hline Variables & Value of Cronbach Alpha \\
\hline Reliability & 0.801 \\
\hline Empathy & $\mathbf{0 . 8 7 4}$ \\
\hline Customer satisfaction & $\mathbf{0 . 8 2 8}$ \\
\hline
\end{tabular}

\section{Results and Discussion}

\section{Frequency Analysis of Service Reliability}

Service reliability is the first independent variable of this study. The frequency analysis for service reliability is given in Table 2. The entries related to the service reliability were inquired about with the help of communication based questionnaires (multiple response options) are presented below

- The signals are clear

- The voice quality is clear and there is no distortion

- The service quality is up to my expectations

- The service quality can be made better

- The call packages are appropriately priced

- The sms packages are appropriately priced

- Internet service is appropriately priced

- Other facilities like caller tunes/sms bundles are appropriately priced

- Performs services right the first time

- Provides services at the promised time

- Keeps customers informed about when services will be performed

- Keeps its packages and services up to date 
The frequency analysis for reliability variable is given below

Table 2.1: Frequency Analysis for Service Reliability

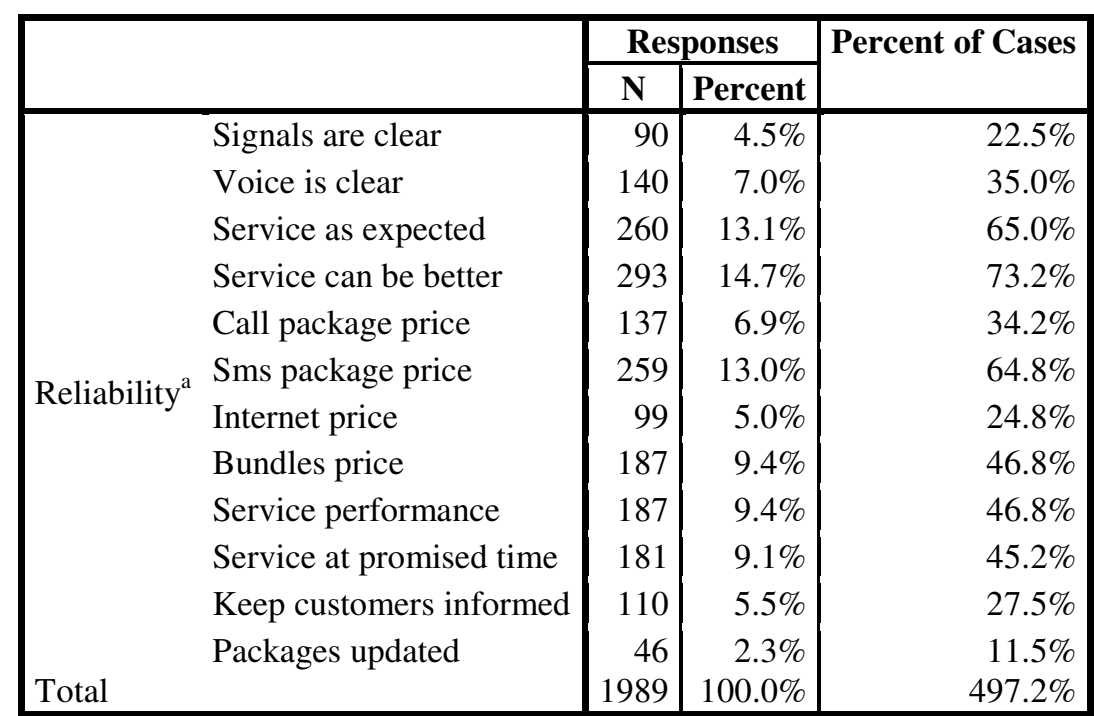

The above table shows that out of 1987 responses 293 which is the highest rated option says that the service can be made better, and second highest rated option of 260 responses say that service is given as expected. This means that although the respondents are satisfied with the services provided by their telecom networks yet most say that service can be further made better. 90 responses report that the signal quality is excellent means they never face any signal problems. Call packages price are reported to be appropriate for 137 responses which means is an average number means that some are satisfied with prices and some are not. 256 responses are in the favor of sms packages that is a high number, means that a lot of people are happy with the sms packages. The responses for internet are just 99 and it needs improvement. 187 responses agree that sms/call bundles are reliable. 110 responses say that the customers are informed on regular bases about the service updates.

Frequency Analysis of Service Empathy

The second independent variable taken for this study is service empathy. Figure 2.2 shows the frequency analysis of service empathy. The multiple response questionnaire items related to the service empathy are presented below

- My call is answered as soon as I call

- The managers/employees always have my best at heart

- Employees show care and concern while talking to me

- The managers/employees give individual attention to my problems and interests

- Service personnel always carefully listen to my complains and requests

- Complain process is convenient to use

- My feedback and suggestions are implemented when possible

- My queries are resolved within time

- I get an immediate solution for my complains 
The frequency analysis for service is given below:

Table 2.2: Frequency Analysis for Service Empathy and Customer Satisfaction

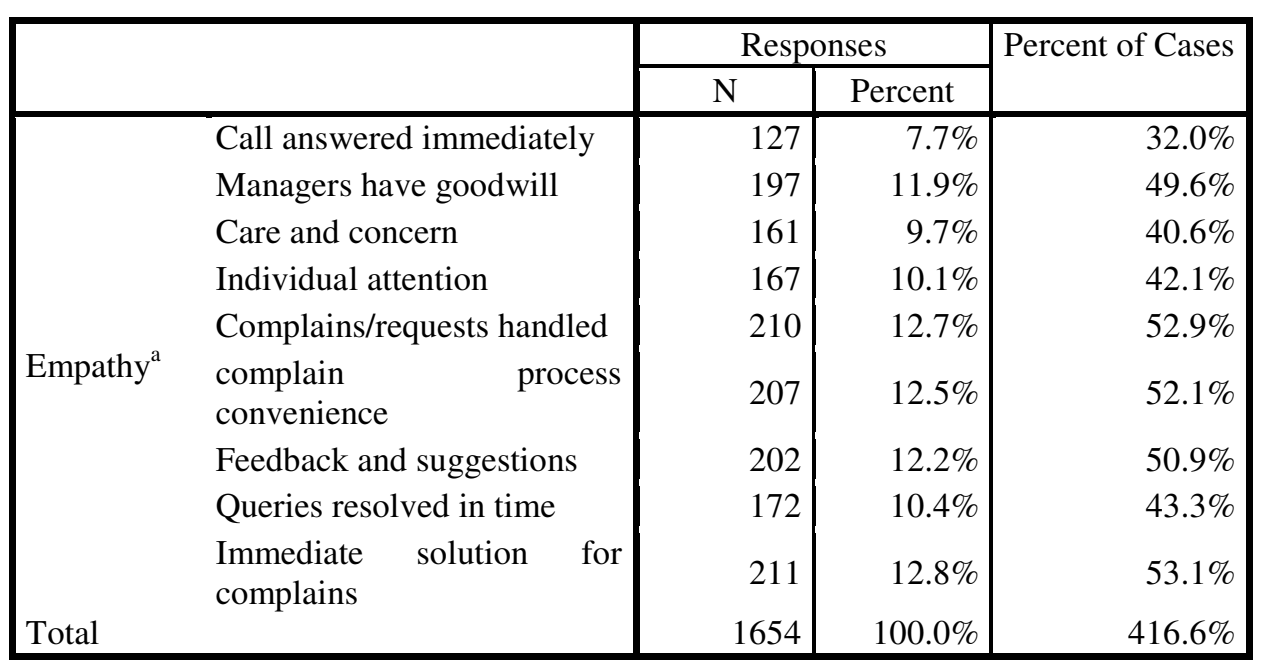

The frequency analysis for service empathy shows total of 1654 responses. It shows that 211 responses favor that they receive immediate responses at the when they complain. 127 responses say that the employees answer the call humbly and 197 responses support that managers have good will for the customers. The responses for care and concern and individual attention are comparatively low i.e. 161 and 167\% respectively which means that these areas need more attention. 207 responses say that the complain process is convenient to use. 202 responses support that they have been asked for giving feedback and suggestions when in encounter with service personnel.

\section{Frequency Analysis of Customer Satisfaction}

The frequency analysis for customer satisfaction is given in table 2.3 which is the dependent variable for the study. The multiple response questionnaire items for customer satisfaction are given below:

- The sms packages satisfaction

- The call packages satisfaction

- The quality of voice call satisfaction

- Signals satisfaction

- The speed of messaging satisfaction

- The attitude of the employees satisfaction

- The pricing satisfaction

- The internet bundles satisfaction

- Sms/call international bundles satisfaction

- Customer support centre satisfaction 
Table 2.3: Frequency Analysis for Customer Satisfaction

\begin{tabular}{|c|c|c|c|c|}
\hline & \multicolumn{2}{|c|}{ Responses } & \multirow[t]{2}{*}{ Percent of Cases } \\
\hline & & $\mathrm{N}$ & Percent & \\
\hline \multirow{11}{*}{ Satisfaction $^{\mathrm{a}}$} & Sms package is satisfactory & 198 & $6.1 \%$ & $49.9 \%$ \\
\hline & Call package is satisfactory & 197 & $10.3 \%$ & $49.6 \%$ \\
\hline & Voice quality is satisfactory & 187 & $9.8 \%$ & $47.1 \%$ \\
\hline & The signals are satisfactory & 210 & $11.0 \%$ & $52.9 \%$ \\
\hline & $\begin{array}{l}\text { Speed of messaging is } \\
\text { satisfactory }\end{array}$ & 190 & $9.9 \%$ & $47.9 \%$ \\
\hline & $\begin{array}{l}\text { Employee attitude is } \\
\text { satisfactory }\end{array}$ & 197 & $10.3 \%$ & $49.6 \%$ \\
\hline & Pricing satisfaction & 193 & $10.1 \%$ & $48.6 \%$ \\
\hline & Internet bundle satisfaction & 116 & $10.3 \%$ & $29.2 \%$ \\
\hline & $\begin{array}{l}\text { International call bundles } \\
\text { satisfaction }\end{array}$ & 21 & $10.6 \%$ & $5.3 \%$ \\
\hline & $\begin{array}{ll}\text { Customer } & \text { support } \\
\text { satisfaction } & \end{array}$ & 204 & $10.6 \%$ & $51.4 \%$ \\
\hline & Recommendation to others & 204 & $1.1 \%$ & $51.4 \%$ \\
\hline Total & & 1917 & $100.0 \%$ & $482.9 \%$ \\
\hline
\end{tabular}

The above table shows total of 1917 responses for customer satisfaction. Overall 210 reponses report that the signals are satisfactory. 198 responses have favored that they are satisfied from the sms packages whereas 197 responses report that call packages are good.197 cases report that the employee attitude is satisfactory.

\section{Cross tabulation - Hypothesis 1}

The purpose of this research is to determine the relationship between the service quality and customer satisfaction. Service quality dimensions reliability and empathy were chosen as independent variables. Following is that first hypothesis.

$\mathrm{H}_{1}$ : There is a significant relationship between reliability dimension of service quality and customer satisfaction in telecom sector of Pakistan.

In the first hypothesis service reliability is the independent variable the effect of which is studied on customer satisfaction that is the dependent variable. This effect is scrutinized through the cross tabulation of these variables which is presented in the following table.

The cross tabulation has for reliability and satisfaction is divided into table 3.1 and table 3.2. 
Table 3.1: Crosstabulation between Reliability and Customer Satisfaction

\begin{tabular}{|c|c|c|c|c|c|c|c|}
\hline & \multicolumn{5}{|c|}{ Satisfaction $^{\mathrm{a}}$} \\
\hline & & & $\begin{array}{l}\text { Sms package is } \\
\text { satisfactory }\end{array}$ & $\begin{array}{c}\text { Call package is } \\
\text { satisfactory }\end{array}$ & $\begin{array}{l}\text { Voice quality is } \\
\text { satisfactory }\end{array}$ & $\begin{array}{l}\text { Signal quality is } \\
\text { satisfactory }\end{array}$ & $\begin{array}{l}\text { SSpeed of messaging } \\
\text { is satisfactory }\end{array}$ \\
\hline & Signals are clear & $\begin{array}{c}\text { Count } \\
\% \text { within } \\
\text { \$Reliblty }\end{array}$ & $\begin{array}{r}28 \\
31.1 \%\end{array}$ & $\begin{array}{r}47 \\
52.2 \%\end{array}$ & $\begin{array}{r}34 \\
37.8 \%\end{array}$ & $\begin{array}{r}48 \\
53.3 \%\end{array}$ & $\begin{array}{r}36 \\
40.0 \%\end{array}$ \\
\hline & Voice is clear & $\begin{array}{c}\text { Count } \\
\% \text { within } \\
\text { \$Reliblty }\end{array}$ & $\begin{array}{r}35 \\
25.2 \%\end{array}$ & $\begin{array}{r}68 \\
48.9 \%\end{array}$ & $\begin{array}{r}60 \\
43.2 \%\end{array}$ & $\begin{array}{r}77 \\
55.4 \%\end{array}$ & $\begin{array}{r}64 \\
46.0 \%\end{array}$ \\
\hline & $\begin{array}{l}\text { Service } \\
\text { expected }\end{array}$ & $\begin{array}{c}\text { Count } \\
\% \text { within } \\
\text { \$Reliblty }\end{array}$ & $\begin{array}{r}74 \\
28.6 \%\end{array}$ & $\begin{array}{r}127 \\
49.0 \%\end{array}$ & $\begin{array}{r}129 \\
49.8 \%\end{array}$ & $\begin{array}{r}143 \\
55.2 \%\end{array}$ & $\begin{array}{r}125 \\
48.3 \%\end{array}$ \\
\hline & $\begin{array}{l}\text { Service can be } \\
\text { better }\end{array}$ & $\begin{array}{c}\text { Count } \\
\% \text { within } \\
\text { \$Reliblty }\end{array}$ & $\begin{array}{r}78 \\
26.8 \%\end{array}$ & $\begin{array}{r}142 \\
48.8 \%\end{array}$ & $\begin{array}{r}133 \\
45.7 \%\end{array}$ & $\begin{array}{r}151 \\
51.9 \%\end{array}$ & $\begin{array}{r}141 \\
48.5 \%\end{array}$ \\
\hline & $\begin{array}{l}\text { Call package } \\
\text { price }\end{array}$ & $\begin{array}{l}\text { Count } \\
\% \text { within } \\
\text { \$Reliblty }\end{array}$ & 47 & $\begin{array}{r}76 \\
55.9 \%\end{array}$ & $\begin{array}{r}55 \\
40.4 \%\end{array}$ & $\begin{array}{r}67 \\
49.3 \%\end{array}$ & $\begin{array}{r}69 \\
50.7 \%\end{array}$ \\
\hline Poliobilitut & $\begin{array}{l}\text { Sms package } \\
\text { price }\end{array}$ & $\begin{array}{c}\text { Count } \\
\% \text { within } \\
\text { \$Reliblty }\end{array}$ & $\begin{array}{r}38 \\
38.4 \%\end{array}$ & $\begin{array}{r}63 \\
63.6 \%\end{array}$ & $\begin{array}{r}40 \\
40.4 \%\end{array}$ & $\begin{array}{r}56 \\
56.6 \%\end{array}$ & $\begin{array}{r}49 \\
49.5 \%\end{array}$ \\
\hline Reliabinty & Internet price & \begin{tabular}{|lc|}
\multicolumn{2}{|c}{ Count } \\
$\%$ & within \\
\$Reliblty \\
\end{tabular} & $33.3 \%$ & $\begin{array}{r}125 \\
48.4 \%\end{array}$ & $\begin{array}{r}126 \\
48.8 \%\end{array}$ & $\begin{array}{r}135 \\
52.3 \%\end{array}$ & $\begin{array}{r}121 \\
46.9 \%\end{array}$ \\
\hline & Bundles price & $\begin{array}{l}\text { Count } \\
\% \text { within } \\
\text { \$Reliblty }\end{array}$ & $\begin{array}{r}61 \\
33.0 \%\end{array}$ & $\begin{array}{r}99 \\
53.5 \%\end{array}$ & $\begin{array}{r}90 \\
48.6 \%\end{array}$ & $\begin{array}{r}100 \\
54.1 \%\end{array}$ & $\begin{array}{r}94 \\
50.8 \%\end{array}$ \\
\hline & $\begin{array}{l}\text { Service } \\
\text { performance }\end{array}$ & $\begin{array}{l}\text { Count } \\
\% \quad \text { within } \\
\text { \$Reliblty }\end{array}$ & $\begin{array}{r}61 \\
33.0 \%\end{array}$ & $\begin{array}{r}99 \\
53.5 \%\end{array}$ & $\begin{array}{r}90 \\
48.6 \%\end{array}$ & $\begin{array}{r}100 \\
54.1 \%\end{array}$ & $\begin{array}{r}94 \\
50.8 \%\end{array}$ \\
\hline & $\begin{array}{l}\text { Service } \\
\text { promised time }\end{array}$ & $\begin{array}{l}\text { Count } \\
\% \quad \text { within } \\
\text { \$Reliblty }\end{array}$ & $\begin{array}{r}61 \\
34.3 \%\end{array}$ & $\begin{array}{r}94 \\
52.8 \%\end{array}$ & $\begin{array}{r}84 \\
47.2 \%\end{array}$ & $\begin{array}{r}98 \\
55.1 \%\end{array}$ & $\begin{array}{r}88 \\
49.4 \%\end{array}$ \\
\hline & $\begin{array}{l}\text { Keep customers } \\
\text { informed }\end{array}$ & $\mid \begin{array}{l}\text { Count } \\
\% \quad \text { within } \\
\text { \$Reliblty }\end{array}$ & $\begin{array}{r}32 \\
29.4 \%\end{array}$ & $\begin{array}{r}50 \\
45.9 \%\end{array}$ & $\begin{array}{r}54 \\
49.5 \%\end{array}$ & $\begin{array}{r}61 \\
56.0 \%\end{array}$ & $\begin{array}{r}52 \\
47.7 \%\end{array}$ \\
\hline & Packages updated & $\begin{array}{l}\text { Count } \\
\% \text { within } \\
\text { \$Reliblty }\end{array}$ & $\begin{array}{r}22 \\
47.8 \%\end{array}$ & $\begin{array}{r}20 \\
43.5 \%\end{array}$ & $\begin{array}{r}24 \\
52.2 \%\end{array}$ & $\begin{array}{r}28 \\
60.9 \%\end{array}$ & $\begin{array}{r}16 \\
34.8 \%\end{array}$ \\
\hline Total & & Count & 116 & 197 & 187 & 210 & 190 \\
\hline
\end{tabular}

The above cross tabulation shows the increasing trend for the call and sms package with respect to the reliability aspect. This means that service is termed more reliable in terms of call "call package" instead of "sms packages". Further talking about the quality again the trend seems to increase which means that "signal quality" is observed to be more reliable than the "voice quality". However, the trend starts decreasing for the sms speed which means that is far less reliable than both voice and signal quality. Similar kind of trend runs for the remaining table. The trend for internet prices is also observed to be increasing. It can be seen that the sms packages are least expected to have any improvements which means that most respondents find sms packages of all four networks more reliable than any other aspect. Service performance for the call packages is observed to be more reliable than for the sms packages; similarly the service performance is found to be more reliable for the signal as compared to the voice quality. The same decreasing to increasing trend for "sms packages" and "call and packages" and "voice quality" and "signal quality" is observed in the entire table, which then decreases in every case for the "speed of messaging" in all service reliability items. 
Table 3.2: Crosstabulation between Reliability and Customer Satisfaction

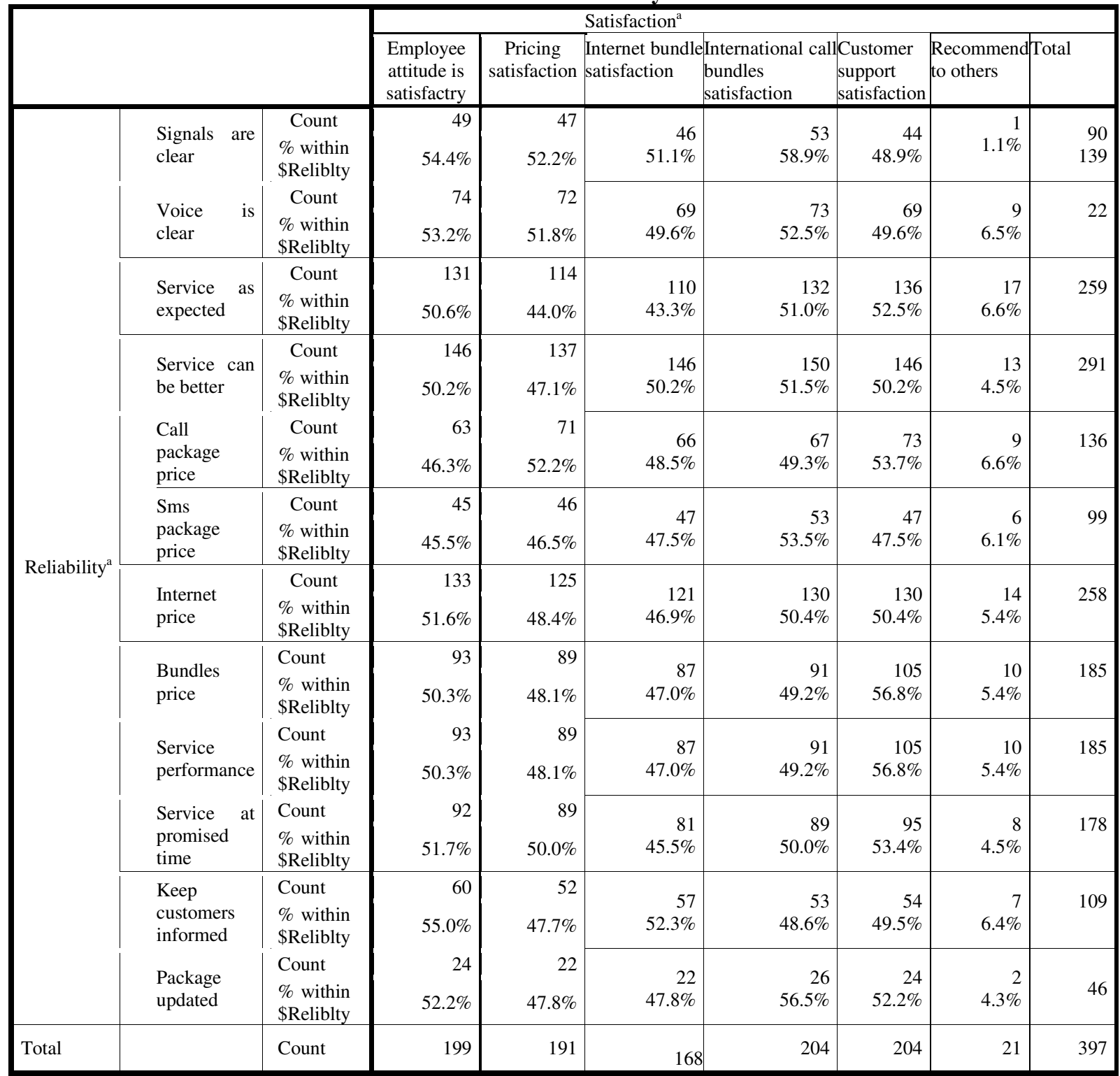

The above table shows the cross tabulation results for remaining reliability and remaining customer satisfaction indicators. The above trend shows increase from the employee attitude to pricing for service reliability. This means that the respondents have favored the employee attitude more over the pricing of the packages. The reliability for pricing satisfaction is therefore shown to be less than reliability for employee attitude dimension. The trend shows sudden decrease for the cases when coming to the internet prices which means that the reliability for internet prices is found out to be comparatively less than pricing of employee attitude. Similarly it is less for the customer support satisfaction and international call bundles but still these values are more than internet prices. Service for all the cases is said to be performed as expected but it has been reported each time that it can be further improved.

Overall trend goes best for the employees' attitude and lowest for the internet bundles. Service reliability in the cases of all four networks has been reported to be more satisfactory for employee attitude and pricing and least satisfactory for internet services and international bundles.

\section{Cross tabulation - Hypothesis 2}

The cross tabulation for service empathy and customer satisfaction is given by Table 4.1 and Table 4.2. Service empathy is taken as second independent variable whereas the customer satisfaction is taken as dependent variable in following hypothesis

$\mathrm{H}_{2}$ : There is a significant relationship between empathy dimension of service quality and customer satisfaction in telecom sector of Pakistan. 
The cross tabulation results for the above hypothesis are presented below

Table 4.1: Crosstabulation between Service Empathy and Customer Satisfaction

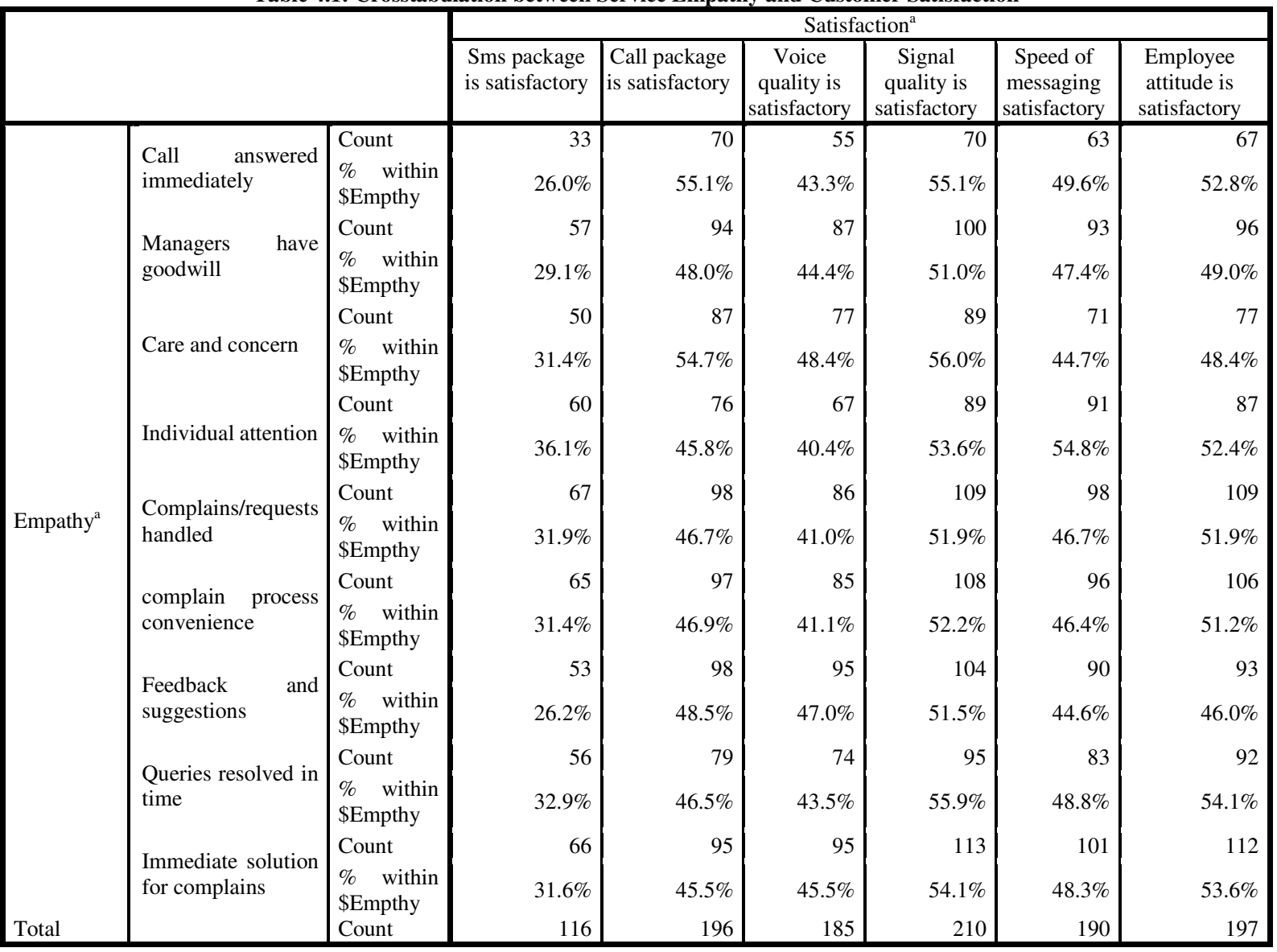

The trend for the above table 4.1 can be seen in a same pattern for all the indicators of empathy and customer satisfaction. It can be seen to increase from decrease and then decrease from increasing for all the horizontal values.

As the sum of all cases of empathy variable are given at the end of table 4.2, it has been reported that the most of the respondents are satisfied with the handling of complain and requests (total $=210$ ) which also means that they are in encounter with employee mostly at the time of complains. Also the trend for "individual attention" is observed to be more than the other indicators of service empathy. Least is observed in all cases for the feedback and suggestions which means that customers' feedbacks and suggestions are not as much asked for during their encounter with telecom personnel. Also most of the responses have supported that managers have goodwill for customers and show care and concern.

The following table 4.2 is the continuation of Table 4.1 which again shows the cross tabulation for service empathy and customer satisfaction. 


\begin{tabular}{|c|c|c|c|c|c|c|c|c|}
\hline & & & \multicolumn{6}{|c|}{ Satisfaction } \\
\hline & & & $\begin{array}{l}\text { Pricing is } \\
\text { satisfactory }\end{array}$ & $\begin{array}{c}\text { Internet } \\
\text { bundle is } \\
\text { satisfactory }\end{array}$ & $\begin{array}{l}\text { International } \\
\text { call bundles } \\
\text { satisfaction }\end{array}$ & $\begin{array}{l}\text { Customer } \\
\text { support } \\
\text { satisfaction }\end{array}$ & $\begin{array}{c}\text { Recommendation } \\
\text { to others }\end{array}$ & Total \\
\hline & answered & Count & 99 & 101 & 99 & 96 & 13 & 196 \\
\hline & immediately & $\%$ within & $50.5 \%$ & $49.6 \%$ & $50.5 \%$ & $49.0 \%$ & $9.4 \%$ & \\
\hline & Men & Count & 67 & 63 & 68 & 66 & 12 & 127 \\
\hline & goodwill & $\%$ within & $51.2 \%$ & $51.5 \%$ & $53.5 \%$ & $52.0 \%$ & $6.6 \%$ & \\
\hline & & Count & 79 & 80 & 81 & 82 & 15 & 159 \\
\hline & Care and concern & $\%$ within & $49.7 \%$ & $50.3 \%$ & $50.9 \%$ & $51.6 \%$ & $9.4 \%$ & \\
\hline & & Count & 92 & 84 & 92 & 79 & 8 & 166 \\
\hline & Individual attention & $\begin{array}{l}\% \text { within } \\
\text { \$Empthy }\end{array}$ & $55.4 \%$ & $50.6 \%$ & $55.4 \%$ & $47.6 \%$ & $4.8 \%$ & \\
\hline & Comnlains/reauests & Count & 103 & 106 & 115 & 108 & 12 & 210 \\
\hline Empathy $^{\mathrm{a}}$ & $\begin{array}{l}\text { Complains/requests } \\
\text { handled }\end{array}$ & $\begin{array}{l}\% \text { within } \\
\text { \$Empthy }\end{array}$ & $49.0 \%$ & $50.5 \%$ & $54.8 \%$ & $51.4 \%$ & $5.7 \%$ & \\
\hline & complain process & Count & 100 & 106 & 113 & 107 & 10 & 207 \\
\hline & convenience & $\begin{array}{l}\% \text { within } \\
\text { \$Empthy }\end{array}$ & $48.3 \%$ & $51.2 \%$ & $54.6 \%$ & $51.7 \%$ & $4.8 \%$ & \\
\hline & Feedback and & Count & 98 & 102 & 100 & 106 & 9 & 202 \\
\hline & suggestions & $\begin{array}{l}\text { \% within } \\
\text { \$Empthy }\end{array}$ & $48.5 \%$ & $50.5 \%$ & $49.5 \%$ & $52.5 \%$ & $4.5 \%$ & \\
\hline & Queries resolved in & Count & 83 & 76 & 89 & 77 & 5 & 170 \\
\hline & time & $\begin{array}{l}\text { \% within } \\
\text { \$Empthy }\end{array}$ & $48.8 \%$ & $44.7 \%$ & $52.4 \%$ & $45.3 \%$ & $2.9 \%$ & \\
\hline & Immediate solution & Count & 96 & 111 & 99 & 102 & 11 & 209 \\
\hline & for complains & $\begin{array}{l}\% \text { within } \\
\text { \$Empthy }\end{array}$ & $45.9 \%$ & $53.1 \%$ & $47.4 \%$ & $48.8 \%$ & $5.3 \%$ & \\
\hline Total & & Count & 193 & 197 & 203 & 203 & 21 & 395 \\
\hline
\end{tabular}

The trend for the above table 4.2 can be seen in a same pattern for all the indicators of empathy and customer satisfaction. It can also be seen to decrease from increase and then again increase to decrease for all the indicators of customer satisfaction.

The least responses for all the cases can be seen for the immediate call answer which means that customers are not satisfied with the call answering efficiency of service reliability. Also the feedback and suggestions do not seem to have a high response which shows that it decreases customer satisfaction. The table also present average responses for convenience of complaint process and resolving of queries in time.

\section{Discussion}

Overall, the results have established some main points to focus. First of all for the reliability dimensions of the service quality, it can be clearly observed that the sms packages are more satisfactory as compared to the call packages. Also the signals are observed to be more satisfactory compared to the voice quality. This means that the network providers need to focus more on the call packages than the sms packages as most of the providers are already offering a lot of cheap sms bundles. Also lowest values have been recorded for the internet bundles and also the international call rates. The reliability of these two factors for customer satisfaction is observed to be the lowest compared to other results. For every case these values are observed to be comparatively low which deduces that network providers need to make the international calling packages as well as internet bundles more reliable (which constitutes price, network quality and other factors) in order to enhance customer satisfaction. Also it can be seen that most of the responses have favored that the services is up to the expectations but more responses favor that they still have a chance to become better than they are.

The results for empathy dimension overall elicit that most responses are in support that the employees give individual attention and also that the complains and requests are carefully handled. This means that the customers usually contact the service personnel when they are facing any problem and they do get individual attention. However, lowest rates are observed to be for the immediate answer to the call. This means that customers do not immediately get in touch with the service employees and have to wait for their answer. This causes dissatisfaction which means that this aspect of empathy dimension needs to improve. Average responses 
are recorded for convenience of complaint process which means that there is a chance for improvement here too. However, good responses are observed for managers' care and concern. Less number of responses are supporting that the feedback and suggestions gets implemented which means there is a chance of improvement here as well.

Both the hypotheses are supported as the percentages of customer satisfaction change with the service quality dimensions of reliability and empathy. Overall it can be established the there is a significant relationship between customer satisfaction and service quality dimensions of empathy and reliability.

\section{Conclusion, Limitations and Implications for Future Research}

This study has been conducted to establish a link between service quality dimensions of reliability and empathy and customer satisfaction in telecom sector of Pakistan. Reliability and empathy dimensions have been selected because they cover almost all major features of telecom services. The primary data was collected from 400 respondents that were users for 4 main mobile networks of Pakistan (i.e. mobilink, zong, telenor and ufone). It has been established that there is a significant relationship between service quality and customer satisfaction.

The first limitation of this result is the unit of Analysis which is Rawalpindi and Islamabad. The responses from all over Pakistan would better help in eliciting the clear results. Also this study does not cover all the dimensions of service quality. In future, research can be done by taking a wider unit of analysis and measuring all service dimensions for any other place like internet services and educational institutes where this kind of research has not yet been conducted in Pakistan.

\section{References}

Appiah-Adu, K. (1999). Marketing Effectiveness and Customer Retention in the Service Sector. The Service Industries Journal, 19(3), 26-41.

Arslan, M., Umair, N., \& Zaman, R. (2014). Effect of Parental Attitude on the Relationship between Children's Exposure to Advertising and their Purchase Request. International Journal of Science Commerce and Humanities, 2(5), 196-210.

Athanassopoulos, A., Gounaris, S. \& Stathakopoulos, V. (2001). Behavioral Responses to Customer Satisfaction: An Empirical Study. European Journal of Marketing, 35 (6), 687-707.

Boshoff, C., \& G. B. (2004). The Relationships between Service Quality, Customer Satisfaction and Buying Intentions In the Private Hospital Industry. South African Journal of Business Management, 35(4), $27-$ 37.

Brady, M. K., \& R. C. (2001). Searching for a consensus on the antecedent role of service quality and satisfaction: An exploratory cross-national study. Journal of Business Research, 51(1), 53-60.

C., M., A. P., \& D. B. (2002). Relationship marketing: Creating Customer Value,.

Choi, K. S., C. W., L. S., L. H., \& K. C. (2004). The Relationships among Quality, Value, Satisfaction and Behavioral Intention in Health Care Provider Choice: A South Korean Study. Journal of Business Research, 58(8), 913-921.

Coyles, S., \& G. T. (2002). Customer Retention is Not Enough. The McKinsey Quarterly.

Dabholkar, P. A. (1995). A Contingency Framework for Predicting Causality between Customer Satisfaction and Service quality. Advances in Consumer Research, 22(1), 101-108.

Gitomer, J. (1998). Customer satisfaction is worthless, customer loyalty is priceless: How to make customers love you, keep them coming back, and tell everyone they know. Austin: TX: Bard Press.

Griffin, J. (1995). Customer loyalty: How to earn it, how to keep it. New York: Lexington Books.

Jones, M. A., \& S. J. (2000). Transaction-Specific Satisfaction and Overall Satisfaction: An Empirical Analysis. Journal of Services Marketing, 14(2), 147-159.

Lovelock, C. H., P. P., \& W. R. (2001). Services Marketing: An Asia-Pacific Perspective (2nd ed.). Australia: Prentice Hall.

MacStravic, R. E. (1977). Marketing Health Care. Gaithersburg, MD: Aspen.

Ojo, O. (2010). The Relationship Between Service Quality and Customer Satisfaction in the Telecommunication Industry: Evidence From Nigeria. BRAND. Broad Research in Accounting, Negotiation, and Distribution, 1(1).

Oliver, R. L. (1981). Measurement and Evaluation of Satisfaction Processes in Retail Settings. Journal of Retailing, 57(3), 25-48.

Parasuraman, Zeithaml, \& Berry,. (1988). SERVQUAL: A Multiple-Item Scale for Measuring Customer Perceptions of Service Quality. Journal of Retailing, 12-40.

Soderlund, M., \& O. N. (2003). Behavioral Intentions in Satisfaction Research Revisited. Journal of Consumer Satisfaction, Dissatisfaction and Complaining Behavior, 16, 53-66.

Spreng, R. A., \& Mackoy, R. (1996). An empirical examination of a model of perceived serviced. Journal of Retailing, 72(2), 201-2014.

Taylor, S. A., \& B. T. (1994). An Assessment of the Relationship between Service Quality and Customer 
Satisfaction in the Formation of Consumers' Purchase Intentions. Journal of Retailing, 70(2), 163-178.

Thompson, K. N., \& G. J. (1994). The Relationship between Quality, Satisfaction, and Recommending Behaviour in Lodging Decisions. Journal of Hospitality \& Leisure Marketing, 2(3), 3-22.

Yi, Y. J., \& L. S. (2004). What Influences the Relationship between Customer Satisfaction and Repurchase Intention? Investigating the Effect of Adjusted Expectations and Customer Loyalty. Psychology and Marketing, 21(5), 351-373.

Zaman, R., \& Arslan, M. (2014). Effects of Pre-Announced Product Characteristics on Customer's Purchase Intention. European Journal of Business and Management, 6(23), 167-172.

Zeithaml, V. A., B. L., \& P. A. (1996). The Behavioral Consequences of Service Quality. Journal of Marketing, 60(2), 31-47. 


\section{Questionnaire}

\section{Section A}

\section{BACKGROUND INFORMATION OF RESPONDENT}

(Please tick where applicable)

A1. Would you please tick which age bracket you fall in?

1) 18 - 25 years

2) 25-32 years

3) 32 - 38 years

4) $38-45$ years

A2. Gender

1) Male

2) Female

A3. Which of the following mobile networks are you using?

1) Mobilink

2) Zong

3) Telenor

4) Warid

\section{Section B}

For this section, choose the option which seems most. Respondents are encouraged to tick more than one option if applicable.

\section{Reliability}

How reliable do you think is the service?

Quality

- The signals are clear

- The voice quality is clear and there is no distortion

- The service quality is up to my expectations

- The service quality can be made better

Price

- The call packages are appropriately priced

- The sms packages are appropriately priced

- Internet service is appropriately priced

- Other facilities like caller tunes/sms bundles are appropriately priced

Time

- Performs services right the first time

- Provides services at the promised time

- Keeps customers informed about when services will be performed

- Keeps its packages and services up to date

Empathy

How empathic are the managers and employees of your telecom service?

Employees Attitude

- My call is answered soon as I call

- The managers/employees always have my best at heart

- Employees show care and concern while talking to me

- The managers/employees give individual attention to my problems and interests

\section{Complain process}

- Service personnel always carefully listen to my complains and requests

- Complain process is convenient to use

- My feedback and suggestions are implemented when possible

- My queries are resolved within time

- I get an immediate response for my complains 


\section{Section C}

Satisfaction

You are satisfied with:

- The sms packages

- The call packages

- The quality of voice call

- Signals

- The speed of messaging

- The attitude of the employees

- The pricing

- The internet bundles

- Sms/call international bundles

- Customer support centre

You will like to recommend others to use this package

I. Yes

II. No 
The IISTE is a pioneer in the Open-Access hosting service and academic event management. The aim of the firm is Accelerating Global Knowledge Sharing.

More information about the firm can be found on the homepage:

http://www.iiste.org

\section{CALL FOR JOURNAL PAPERS}

There are more than 30 peer-reviewed academic journals hosted under the hosting platform.

Prospective authors of journals can find the submission instruction on the following page: http://www.iiste.org/journals/ All the journals articles are available online to the readers all over the world without financial, legal, or technical barriers other than those inseparable from gaining access to the internet itself. Paper version of the journals is also available upon request of readers and authors.

\section{MORE RESOURCES}

Book publication information: http://www.iiste.org/book/

\section{IISTE Knowledge Sharing Partners}

EBSCO, Index Copernicus, Ulrich's Periodicals Directory, JournalTOCS, PKP Open Archives Harvester, Bielefeld Academic Search Engine, Elektronische Zeitschriftenbibliothek EZB, Open J-Gate, OCLC WorldCat, Universe Digtial Library, NewJour, Google Scholar

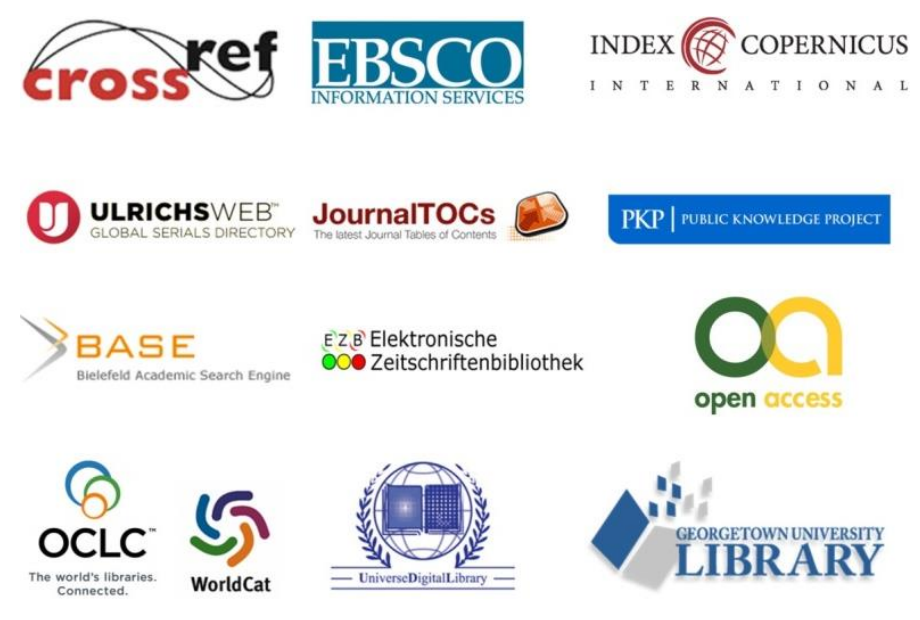

